\title{
The Determination of Malathion Residues in Tobacco and Tobacco Smoke Condensate*
}

\author{
by H. Hengy and J. Thirion \\ Rupert International (Pty.) Ltd., Stellenbosch, Republic of South Africa
}

\section{INTRODUCTION}

The p-nitrobenzylpyridine reaction (NBP) as described by Getz et al. (1) was modified and adapted to determine Malathion in tobacco and smoke condensate.

The cleanup procedure comprised the extraction of tobacco or smoke condensate with acetonitrile, partitioning between $\mathrm{n}$-hexane and acetonitrile, column chromatography on Florisil and activated charcoal and finally thin layer chromatography on Silica Gel G plates.

This method could estimate the Malathion content on tobacco and in smoke condensate in concentrations as low as 0.05 parts per million.

In conjunction with this work the transfer rate of Malathion from cigarettes into the main-stream smoke was also determined.

Although the colorimetric method of Norris et al. (2) and a number of modifications thereof $(3,4,5)$ were used in some cases (6) to determine Malathion on tobacco, we found the sensitivity insufficient for our purposes.

A gas chromatographic method to determine organophosphorus pesticide residues (including Malathion) on tobacco was recently developed by Nesemann and Seehofer (7).

\section{EXPERIMENTAL}

\section{Reagents}

p-Nitrobenzylpyridine solution (NBP) (prepared daily by dissolving recrystallized material in acetone to obtain a $2 \%$ solution), cyclohexylamine, Florisil (Hopkins and Williams), charcoal (Noritex, 16-100 mesh), Silica Gel $G$ (Merck) and palladium chloride.

All the solvents (pro-analysi quality) were redistilled before use.

\section{NBP reaction}

Standard solutions of Malathion were prepared. Aliquots of these solutions containing 4-30 $\mu \mathrm{g}$ of Malathion were treated as follows:

\footnotetext{
- Received for publication: 26th January, 1970.
}

The solvent was evaporated in a Getz tube (1) under reduced pressure on a rotary evaporator. $0.4 \mathrm{ml}$ of the NBP solution was added to the residue and the test tube heated for exactly 3 minutes under reflux in a $175-180^{\circ} \mathrm{C}$ preheated oil bath. The tube was then cooled in ice water and $0.1 \mathrm{ml}$ cyclohexylamine was added followed by dilution to a volume of $3 \mathrm{ml}$ with ethyl acetate. The absorbance was immediately measured in $I \mathrm{~cm}$ path length cells at $520 \mathrm{~m} \mu$ against an ethyl acetate blank. A linear curve for Malathion concentrations up to $35 \mu \mathrm{g}$ was obtained. The reproducibility of the observations was $\pm 5 \%$.

\section{DETERMINATION OF MALATHION ON TOBACCO}

a) Extraction of tobacco

10 Grams of anhydrous sodium sulphate was added to $25 \mathrm{~g}$ samples of ground tobacco and the Malathion extracted with warm acetonitrile $\left(40^{\circ} \mathrm{C}\right)$ by shaking for 1 hour.

\section{b) Cleanup}

1. Partitioning between immiscible solvents: In order to remove the major part of the waxes and coloured materials, the acetonitrile solution was washed three times with 50-100 $\mathrm{ml} \mathrm{n}$-hexane portions. The combined hexane solutions were washed once with $50-100 \mathrm{ml}$ acetonitrile and combined with the initial acetonitrile extract. The acetonitrile was evaporated to $20 \mathrm{ml}$. To this solution $5 \mathrm{~g}$ of Florisil was added and the solvent removed completely. The residue was swirled with $20 \mathrm{ml}$ hexane/ether $(4: 1)$ and the slurry evaporated to dryness.

2. Column chromatography: The powder obtained in 1 . was quantitatively brought onto a glass column of $300 \mathrm{~mm} \times 18 \mathrm{~mm}$ inside diameter, wet padked with $15 \mathrm{~g}$ of Florisil. The Malathion was eluted with $300 \mathrm{ml}$ hexane/diethyl ether $(4: 1)$, the eluate evaporated to dryness, and the residue dissolved in $1 \mathrm{ml}$ of acetone.

3. Thin layer chromatography: Silica Gel G plates $(20 \mathrm{~cm} \times 20 \mathrm{~cm})$ were prepared with $10 \mathrm{~g}$ of Silica Gel 
$\mathrm{G}$ (Merck) and $25 \mathrm{ml}, 0.1$ molar phosphate buffer (pH 6.5) solution. The plates were activated for one hour at $120^{\circ} \mathrm{C}$.

The sample was applied over two-thirds of the plate. A reference, containing $10 \mu \mathrm{g}$ of Malathion was spotted on the remaining third of the plate. The plates were developed for a distance of $15 \mathrm{~cm}$ in a benzene/chloroform $(3: 2)$ system. Subsequently, the part of the plate which contained the tobacco sample was covered, while the rest of the plate was sprayed with a $I \%$ solution of palladium chloride to which a few drops of hydrochloric acid was added. Malathion appeared as a yellow spot with a $R_{f} \times 100$ value of $36-38$.

A zone with a $R_{f}$ value corresponding to that of Malathion was quantitatively scraped from the plate and extracted with ca. $40 \mathrm{ml}$ of acetonitrile. The amount of Malathion was determined with the NBP reaction, as described previously.

\section{Table 1 Recoveries of Malathion added to tobacco}

\begin{tabular}{c|c|c}
\hline $\begin{array}{c}\text { Amount added } \\
\text { in ppm }\end{array}$ & $\begin{array}{c}\text { Found } \\
\text { ppm }\end{array}$ & $\begin{array}{c}\text { Recovery } \\
\%\end{array}$ \\
\hline 0.090 & 0.080 & 89 \\
0.180 & 0.162 & 90 \\
0.58 & 0.530 & 92 \\
2.0 & 1.85 & 92.5 \\
50 & 44 & 88 \\
\hline
\end{tabular}

Duplicate samples of tobacco treated with known concentrations of Malathion were analysed. The results are given in Table 1.

\section{c) Samples}

The above procedure was employed to analyse the Malathion content of air-cured, flue-cured and cigarette tobaccos. For each determination $25 \mathrm{~g}$ of ground tobacco was worked up. Duplicate analyses were made and the colour measured against a solvent blank (Table 5). The control obtained from an untreated tobacco sample was colourless.

\section{DETERMINATION OF MALATHION IN SMOKE CONDENSATE}

\section{a) Recovery experiments}

The method for the determination of Malathion in the main-stream smoke of cigarettes was evaluated by conducting recovery experiments on cigarette smoke condensate with known amounts of Malathion added.

\section{b) Cleanup}

A ten $\mathrm{ml}$ tar solution, equivalent to $1 \mathrm{~g}$ of smoke condensate, was used for each recovery experiment.

\section{Partitioning between acetonitrile and n-hexane}

This step was carried out as described for the tobacco samples, the only difference being that the slurry was prepared with $10 \mathrm{~g}$ of Florisil.

\section{Column chromatography}

Column $A$ The material obtained in 1. was quantitatively transferred to a glass column packed with $10 \mathrm{~g}$ of Florisil, and the Malathion eluted from the column with $300 \mathrm{ml}$ hexane/ether $(4: 1)$.

Column $B$ For further cleanup a second column packed with active carbon was used. The eluate obtained from column A was evaporated to dryness, the residue taken up in $20 \mathrm{ml}$ acetone and brought onto a column packed with $5 \mathrm{~g}$ of acetone washed carbon. The column was slowly eluted with $150 \mathrm{ml}$ acetone. The eluant was concentrated under reduced pressure to a final volume of I ml. The final concentration step was carried out in a test tube.

\section{Thin layer chromatography}

Thin layer chromatography was carried out as described for the tobacco samples. In this case the developing system was benzene/diethyl ether (9:1). The $R_{f} \times 100$ value obtained for Malathion was 50-54. To establish that no changes in the $R_{f}$ value of Malathion in the presence of smoke condensate took place, a reference of Malathion and tar was also spotted on the plate. No difference in behaviour was observed. A zone with a $R_{f}$ value corresponding to that obtained for Malathion, was scraped from the plate and determined as described for the tobacco samples. A $1 \mathrm{~g}$ unspiked sample of smoke condensate which was treated in the same way served as control. The control sample yielded an absorption value of 0.08 . Duplicate samples of smoke condensate fortified with 14-112 $\mu \mathrm{g}$ of Malathion per $I \mathrm{~g}$ of smoke condensate were analysed. The averages of the values found are given in Table 2 .

Table 2 Recovery of Malathion from cigarette smoke condensate

\begin{tabular}{c|c|c}
\hline $\begin{array}{c}\text { Malathion added } \\
\text { to tar (ppm) }\end{array}$ & $\begin{array}{c}\text { Malathion } \\
\text { (ppm) found }\end{array}$ & $\begin{array}{c}\text { Recovery } \\
\%\end{array}$ \\
\hline 14 & 11.5 & 82 \\
28 & 22 & 78 \\
56 & 45 & 80 \\
112 & 85 & 76 \\
\hline
\end{tabular}

Confirmation of the presence of Malathion was obtained by determining $R_{f}$ values in different developing systems. To ensure that Malathion and not Malaoxon (0,0-dimethyl, S-[1,2-bis-(ethoxycarbonyl)ethyl]monothiophosphate) was being determined, the $R_{f}$ values of these two

Table $3 R_{f} \times 100$ values of Malaoxon and Malathion

\begin{tabular}{|c|c|c|c|}
\hline Developing system & & $\begin{array}{l}R_{f} \text { values } \times 100 \\
\text { for Malathion }\end{array}$ & $\begin{array}{l}R_{f} \text { values } \times 100 \\
\text { for Malaoxion }\end{array}$ \\
\hline $\begin{array}{l}\text { Benzene/ether } \\
\text { Benzene/ } \mathrm{CHCl}_{3} \\
\text { Hexane/acetone }\end{array}$ & $\begin{array}{l}(9: 1) \\
(3: 2) \\
(4: 1)\end{array}$ & $\begin{array}{r}52-54 \\
36-38 \\
42-43\end{array}$ & $\begin{array}{c}9-10 \\
21-23 \\
5\end{array}$ \\
\hline
\end{tabular}


components were compared in various thin layer chromatography systems. This was necessary because Malaoxon, an oxidation product of Malathion, also gives a positive reaction with the NBP reagent and palladium chloride.

Malaoxon was synthesized by oxidation of Malathion with nitric acid, according to the method as described by Johnson (8).

$R_{f} \times 100$ values for Malathion and Malaoxon were determined on Silica Gel G plates employing three different solvent systems (see Table 3). With palladium chloride as spraying reagent (9) a yellow spot for Malathion was obtained immediately after spraying, while in the case of Malaoxon full intensity was only obtained after a few hours of exposure. It was also observed that the sensitivity was lower for Malaoxon.

\section{TRANSFER OF MALATHION FROM TOBACCO INTO THE MAIN-STREAM SMOKE}

\section{a) Experimental cigarettes}

A solution of Malathion in ethanol was sprayed onto two tobacco samples employing a chromatographic sprayer, to obtain concentrations of approximately 100 $\mathrm{ppm}$ and $30 \mathrm{ppm}$. Cigarettes were made from this tobacco. The determination of the Malathion content of these samples and the smoking of cigarettes were conducted simultaneously. For the thin layer chromatography step only $1 / 20$ th and $1 / 10$ th of the column eluates of 100 and $30 \mathrm{ppm}$ samples were used respectively in order to prevent overloading of the plates.

\section{b) Smoking of the cigarettes}

The smoke condensate of 50 cigarettes was collected on Cambridge filters attached to gas washing bottles containing $100 \mathrm{ml}$ of acetonitrile each and cooled in an ice bath. The usual smoking parameters were used. The same number of untreated cigarettes, smoked in similar fashion, served as control. The Cambridge filters and the acetonitrile solutions were combined and the mixture stirred until the filters had completely disintegrated. The solvent was removed and the determination carried out as described. The weight of the butts and paper were determined to obtain the weight of tobacco consumed. The transfer rates are given in Table 4 (see results).

A semi-quantitative determination of Malathion by visual comparison of the spots was also carried out to confirm the quantity of Malathion found in the above experiment.

\section{RESULTS AND DISCUSSION}

\section{Colour reaction}

According to Getz, the cyclohexylamine should be added in a diluted form prior to heating, resulting in the formation of the chromophoric system during the heating process. When the NBP reaction was carried out in this way, consistently higher distribution of the values was obtained, as compared with the modified method, i. e. by adding the base afterwards.

The improved results obtained with the modified method could be due to the fact that the base was added after the nucleophilic centre of the NBP had reacted with Malathion. In this case the chromophoric compound was not exposed to the base during the heating as in the case with the Getz method. It is well known that $\mathrm{N}$-phosphoryl-4-(4-nitrobenzylidene)1,4-dihydropyridines are not very stable in a basic medium.

When using the NBP reagent, it is of importance that all reagents and solvents used should be absolutely free of NBP positive reacting compounds.

Because a number of compounds, e. g. alkylating and acylating substances (10) give a positive reaction with NBP, the colour reaction is not specific for Malathion. To increase the specificity it was necessary to employ an appropriate cleanup procedure.

\section{Cleanup}

Satisfactory results were achieved by employing solvent partitioning between acetonitrile and n-hexane, and column and thin layer chromatography. It is even possible to increase the specificity further by using different thin layer chromatographic systems.

The Silica Gel G plates were prepared with 0.1 molar phosphate buffer ( $\mathrm{pH}$ 6.5) to prevent the possible decomposition of Malathion on the plates. Efficient tank saturation was important. The detection limit for Malathion with a $1 \% \mathrm{PdCl}_{2}$ solution as spray reagent was 2 to $5 \mu \mathrm{g}$. The NBP reagent was also applied as a spraying reagent (11) to confirm the presence of Malathion and Malaoxon. Using this reagent, these two components appeared as blue spots, Malaoxon being slightly more sensitive. To ascertain that Malathion was determined the $R_{f}$ values of Malathion and Malaoxon were compared, using different solvent systems. The $R_{f}$ values indicated that the polarity of Malaoxon is significantly higher than that of Malathion. This excluded the possibility that Malaoxon would interfere with the determination of Malathion when using the cleanup procedure as described. It is also unlikely that other possible NBP positive degradation products of Malathion were determined because of the differences in reactivity and behaviour of these products.

Whether the oxidation product Malaoxon is formed from Malathion in the smoking process and in what concentrations is not known.

\section{Analysis}

Table 4 Transfer of Malathion from tobacco into the main-stream smoke of cigarettes

\begin{tabular}{|c|c|c|c|c|}
\hline \multicolumn{2}{|c|}{$\begin{array}{l}\text { Malathion content } \\
\text { of tobacco in }\end{array}$} & \multirow{2}{*}{$\begin{array}{l}\text { Weight of } \\
\text { smoked } \\
\text { tobacco } \\
\text { in } g\end{array}$} & \multirow{2}{*}{$\begin{array}{l}\text { Mala- } \\
\text { thion } \\
\text { in tar } \\
\text { in } \mu g\end{array}$} & \multirow{2}{*}{$\begin{array}{c}\text { Transfer } \\
\%\end{array}$} \\
\hline$\mu \mathrm{g}$ & $\mathrm{ppm}$ & & & \\
\hline $\begin{array}{l}3750 \\
3800\end{array}$ & 90.2 & $\left.\begin{array}{l}41.6 \\
42.1\end{array}\right\} 50$ cig. & $\begin{array}{l}350 \\
327\end{array}$ & $\begin{array}{l}9.4 \\
8.6\end{array}$ \\
\hline $\begin{array}{l}725 \\
705\end{array}$ & 31 & $\left.\begin{array}{l}23.3 \\
22.7\end{array}\right\}$ & $\begin{array}{l}60.6 \\
56.6\end{array}$ & $\begin{array}{l}8.4 \\
8.0\end{array}$ \\
\hline
\end{tabular}


Table 5 Malathion content of cigarettes and leaf tobacco*

\begin{tabular}{l|c}
\hline & $\begin{array}{c}\text { Malathion content } \\
\text { in ppm }\end{array}$ \\
\hline Virginia blended cigarettes & $<0.05$ \\
Flue-cured tobacco & $<0.05$ \\
Air-cured tabacco (1968 crop) & $0.1-0.12$ \\
\hline
\end{tabular}

* The values are expressed on a dry weight basis

\section{SUMMARY}

A method was developed to determine Malathion on tobacco and in smoke condensate at levels of $0.05 \mathrm{ppm}$ and above. A study on the Malathion content of leaf tobacco, cigarette tobacco, and the transfer rate from cigarettes into the main-stream smoke was made. The analysis revealed that the air-cured tobacco contained $0 . x \mathrm{ppm}$ of the pesticide, while the flue-cured samples and cigarettes contained less than $0.05 \mathrm{ppm}$. The transfer studies indicated that approximately $91-92 \%$ of Malathion is lost during the smoking of cigarettes.

\section{ZUSAMMENFASSUNG}

Zur Bestimmung von Malathion-Rückständen in Tabak und Rauchkondensat wurde eine Methode entwickelt, welche es erlaubt, Malathion bis zu einer Konzentration von $0,05 \mathrm{ppm}$ nachzuweisen. Es wurden der Malathiongehalt von Blattabak und von Cigarettentabak sowie die Uberführungsrate dieses Insektizids von Cigaretten in den Hauptrauch untersucht. Die Analyse ergab, daß die "air-cured"-Tabakproben o,I ppm, die "flue-cured"Proben und der Cigarettentabak weniger als $0,05 \mathrm{ppm}$ dieses Insektizids enthielten. Die Untersuchungen zur Ermittlung der Übergangsrate zeigten, daß ungefähr 91-92\% des Malathions beim Rauchen von Cigaretten verlorengehen.

\section{RESUME}

Une méthode a été développée pour la détermination de résidus de Malathion dans le tabac et dans le conden- sat de la fumée. Le procédé analytique décrit permet de doser de faibles concentrations de Malathion jusqu'à la limite inférieure de $0,05 \mathrm{ppm}$. On a examiné la teneur en Malathion de feuilles de tabac et de scaferlati ainsi que le taux de transfert du tabac dans le courant principal de la fumée. L'étude a révélé que le tabac »aircured « contenait $0,1 \mathrm{ppm}$ du pesticide et que les échantillons du tabac »flue-cured» et le tabac à cigarettes contenaient moins de $0,05 \mathrm{ppm}$. L'examen de la récupération a montré qu'environ $91-92 \%$ du Malathion se. perdent pendant le fumage des cigarettes.

\section{REFERENCES}

1. Getz, M. E., Watts, R. R.: J. Assoc. Offic. Agr. Chemists 47 (1964) 1094.

2. Norris, M. V., Vail, W. A., Averall, P. R.: J. Agr. Food Chem. 2 (1954) 570.

Norris, M. V., Easter, E. W., Fuller, L. T., and Kuchar, E. J.: J. Agr. Food Chem. 6 (1958) 111. .

3. Rossouw, S. D.: S. A. J. Agr. Science 4 (1961) 435.

4. Orlosky, E. J.: J. Assoc. Offic. Agr. Chemists 47 (1964) 248.

5. Weisenberg, E., Gertner, S., Schoenberg, J.: Analyst 93 (1968) 443.

6. Tobacco Research Institute, Rustenburg, Rep. of South Africa: Personal communication 1968.

7. Nesemann, E., and Seehofer, F.: CORESTA Information Bulletin, Abstr. 5403 (1968).

8. Johnson, G.: US Patent 2,713,018 (1955) (CA 2114a, 1956).

9. Bäumler, J., Rippstein, S.: Helv. Chim. Acta 44 (1961) I162.

10. Sawicki, E., Bender, D. F., Hauser, T. R., Wilson, R. M., Jr., and Meeker, J. E.: Analytical Chemistry 35 (1963) 1479.

11. Watts, R. R.: J. Assoc. Offic. Agr. Chemists 48 (1965) 1161.

The authors' address:

Rupert International (Pty.) Ltd., Research Department, Private Bag 5095, Stellenbosch, Republic of South Africa 